\title{
The AscLeptad:
}

A Book of Original Research and Observation in the Science, Art, and Literature of Medicine, Preventive and Cnrative. Price 2s. 6d.

BY B. W. RIOHARDSON, M.D., F.R.s.

Pablished Quarterly by

Longyans, Green \& Co., Paternoster Row, London.

Now ready, the Second Edition of

FAGGE'S MEDICINE.

Revised and Edited

By DR. P. H. I'YE-SMITH, F.R.S., Physician to Guy's Hospital.

N.B.-In this edition the Section on Insanity has been supplied by Dr. G. H. SAvAG $x$ Two volames, 8vo, 38s., cloth ; 448., half-Persian.

London: J. \& A. Churchill, 11, New Burlington Street.

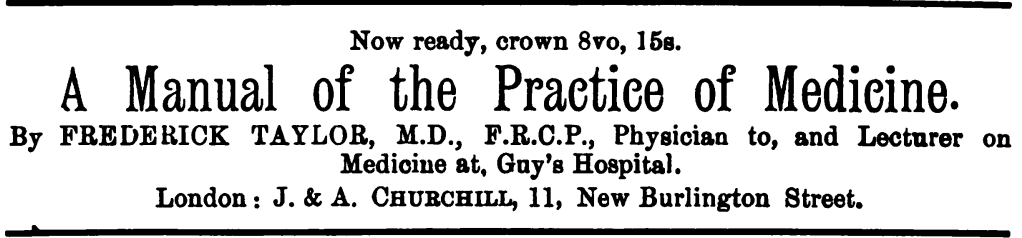

Now ready, 8vo, oloth, 21s., half-calf, 25s.

A Dictionary of Practical Medicine By various Writers.

Edited by JAMES KINGSTON FOWLER, M.A., M.D., F.R.C.P., Senior dssistant

Physician to, and Lecturer on Pathological Anatomy at, the Middlesex

Hospital ; Senior Assistant Physician to the Hospital for Consumption and

Diseases of the Chest, Brompton.

London : J. \& A. Churchinr, 11, New Burlington Street.

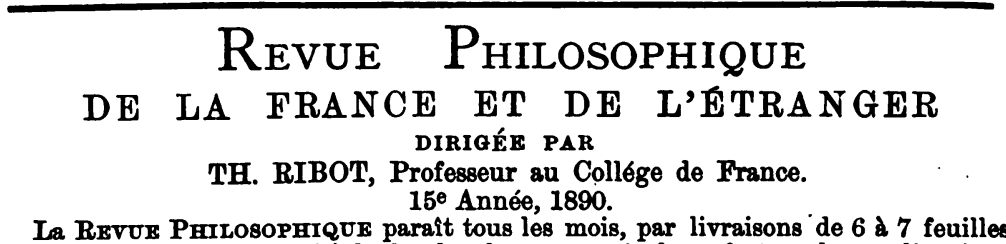

La Revor Phirosophreve parait tous les mois, par livraisons de 6 a 7 feuilles 680 pages chacun.

Prix D'Abonnement.-Un an, pour Paris, 30 francs; Pour les départements et l'étranger, 33-francs; Ia livraison, 8 francs.

A Parienchez FEIX ALCAN, 108, Boulevard Saint-Germain.

\section{CENTRALBLATT FÜR NERVENHEILKUNDE UND PSYCHIATRIE \\ Herauggegeben von ErLenuryer, Charcot, van Drventer, Irriand Kowalewsiji, Lange, Lombroso, Obersteiner, Shguin. \\ Redigirt von Dr. KURELLA.}

Preis 12 Mark. 


\section{In the Prese, A DICTIONARY OF PSYCHOLOGICAL MEDIGINE \\ Giving the Definition, Etymology and Synonyms of the Terms used in Medical Psychology, with the Symptoms, Pathology and Treatment of the recognised forms of Mental Disorder; together with the Law of Lunacy in Great Britain and Ireland. \\ Edited BY D. HACK TUKE, M.D., LL.D. \\ London: J. \& A. Churcarru, 11, New Burlington Street.}

Thirty-meven Coloured Plates, imp. 8vo, 40s.

An Atlas of the Central Nervous System and CRANIAL NERVES, from the larger work of Hirschfeld and Lóveille. Fdited by HOWARD H. TOOTH, M.D., F.R.C.P., Assistant Physician to the National Hospital for the Paralysed and Epileptic.

London: J. \& A. Churchill, 11, New Burlington Street.

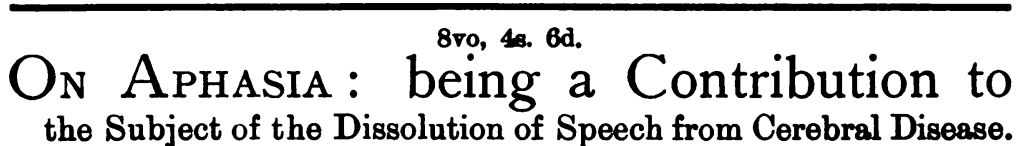

By JAMES ROSS, M.D., F.R.C.P.,

Senior Assistant Physician to the Royal Infirmary, Manchester.

London : J. \& A. ChURCHILL, 11, New Burlington Street.

Just pablished, Second Edition, grently enlarged, 8vo, 16s.

On ApHASia or Loss of SPEEch,

AND THE LOCALISATION OF THE FACULTY OF ARTICULATE LAN. GUAGE. By FREDERICK BATEMAN, M.D., F.R.C.P., Senior Physioian to the Norfolk and Norwich Hospital.

London: J \& A. ChurcBill, 11, New Burlington Street.

Now ready, Third Edition, with 12 Plates and 83 Woodcnts, comprising Original Illustrations of the Changes in the Eye in Diseases of the Brain, Kidneys, etc., 8vo, $16 \mathrm{~s}$.

A Manual and Atlas of Medical Ophthalmoseopy.

By W. R. GOWERS, M.D., F.R.S. Assisted by R. MARCUS GUNN, F.R.C.8., Surgeon to the Royal London Ophthalmic Hospital.

London: J. \& A. CaurcBile, 11, New Barlington Street.

Fourth Edition, 12 Plates (4 being Coloured), 8vo, 25s.

\section{Manual of Psychological Medicine.}

BY

J. C. BUCKNILL, M.D., F.R.C.P., F.R.S., and D. HACK TUKE, M.D., F.R.C.P.

"It is not too much to say that it is the best and most farourably known to the medical and legal professions, by both of whom it is quoted as the highest anthority. It has acquired this enviable standing from the high reputation of its anthors, from the correctness of the views and opinions expressed, and from its fulness. More than any work by English anthors it deals with the subject of insanity in all its relations."-Amer. Journ. of Imsanity.

London: J. \& A. Churchill, 11, New Burlington Street. 


\section{CONTHETS OF No. 154-JULY, 1890.}

\section{PART I.-ORIGINAL ARTICLES.}

O. Theodore Elwart, H.D.-Oycling for the Insane.

B. A. Z. Strahan, M.D.-The Propagation of Insanity and Allied Neuroses.

George M. Robertson, M,B.-Does Manla inelade two distinet varietles of Insanity, and ahould it be sub-divided?

Clinical Notes and Cases. - The Life History of a Malingering Criminal ; by J. Munar, M.B.Case of Hamurrhage into Pons Varolit; by $J$. Rokte, M.D.-Case of intracrsnial Tumour; by Dr. C. Noloman. - Suggestion during Hypuosis in the Insans; Notes of Pathologlcal Spedint, exh red

Cocasionsl Notes of the Quarter. -Fire at the Montreal Asylum,-Alleged Inerease of Lanecy in Lincolnshire.-Mechanicel Restraint.-Sollbede.-Shall the Statintical Year of Acylums be altered?

\section{PART II.-REVIEWS.}

Nourelle Iconograplie de la Salpettriere ; par PAOr Riciren, \&c.-An Experimental Stady in the Domain of Hypotism; by Dr. I. Fon KrafFT-Ersikg. Translated by C. G. Chaddock, M.D.-Anatomis Artistique; par lo Dr. PAve EjeuEr, - Les Diftoranes et les Maladles dans IArt; jar M. II.

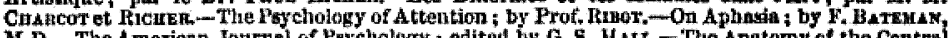
M.D.-The American Journal of Paychology ; edited by G.S. HaLt.-The Anatomy of the Central Nervous Orghns; by Dr, OszustenNen,-The National Medical Dictionary; by J. B. Brulves, M.D. - A Jew Medieal Dietionary ; by G. M. Goun. M.D.-Terminologia Medien Polyglotta, ou Dictionnatre International de "Termes; by Dr. T. MAxw ELL. Nervous Exhansilon ; by G. M. BEAnD, M.D.-Headache and Neuralgia ; by J. L. Consixa, M.D. $-A$ System of Practical and

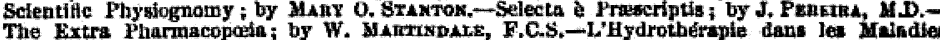

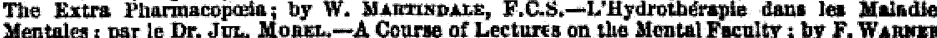
Mentales i psr le Dr. JuL. Monkn,-A Course of Lectures on the Mental Facuity ; by F. Warurze, Insanity; by CuAntes MERCiEn, M.B.

\section{PART III.-PSYCHOLOGICAL RETROSPECT.}

1. Asylum Reporta for 1889.

2. Freneh and Belgian Retrospect ; by D. HAcE Toxz, F.R.C.P.

3. Crimltal Anthropology ; by HAVELocx ELLts.
4. Germun Retrospect; by W. W. IBgLAND, M.D.

\section{PART IV.-NOTES AND NEWS.}

Quarterly Mreeting of the Medico-Poychological Associntion, held at Betblem Royal Hospital, May 15th 1890,-Memoranda on the New Lnnncy Act, 1890. - Insurrection at the Bicettre,-Internationa Medico-Scientifie Exhlibition, Beriln, 1890,-A Handsome Donstion,-The Annual Meeting of the

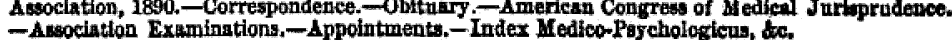

\section{CONTENTS OF N0, 155,-OCTOBER, 1880.} PART I.-ORIGINAL ARTICLES.

D. Xellowlees, M.D.-Presidential Address, dellvered at the Anntal Meeting of the MedicoPsychological Association, held at the Hoyal Asylum, Gartnavel, Glangow, July 24, 1890.

James Howden, M.D.-The Heating, Ventilation, and Electric Lighting of the Hospital at the Montrose Asylum.

Theo. B. Hyslop, M.D. - Sunstroke and Insanity.

W. Johnson Smyth, M.D.-An Inquiry tito the Blood and Urine of the Insane.

Olinical Notes and Cases.- Notes of $\Delta$ Case of Epilspsy in which the Vertebral Artery was tied; by Tetarono SMrTu, M.D.-Parotitls in the Insane; by Taro, B. Hrstop, M.D.

Occastonal Notes of the Quarter.-The Annal Mecting.-New Hospital for the Insane at Montren], - Hypnotism and the British Medical Association.-An Ont-Pattent Department at the tion to inquire into the question of Bystematlc Training of Attendants.

\section{PART II.-REVIEWS.}

Forty-fourth Report of the Commissioners in Lunacy, Ist July, 1800,-An Epltome of the Synthetic

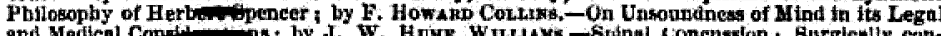

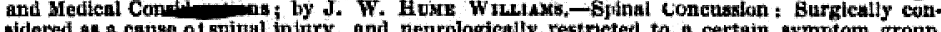
sidered as a cause o1 spinal injury, and zeurologically restrieted to a certain symptom group.

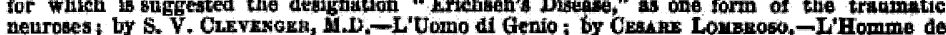
gentie ; by CEsame lourskoso.

PART III.-PSYCHOLOQICAL RETROSPECT,

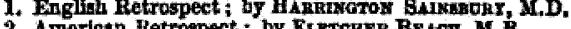

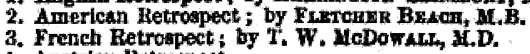

4. Austrian Retrospech

PART IV.-NOTES AND NEWS.

Annual Meeting of the Medico-Paychologtcal Aasoclatton, held on Thursday, Jufy 24, in the Royal Asylum, Garthavel, Glasgow,-Britash Medical A ssociation: Birminghiam Meeting.-Blistering

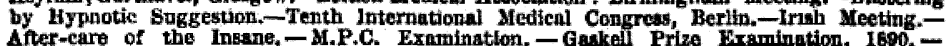
After-eare of the Insane, - M.P.C. Examination, -G 


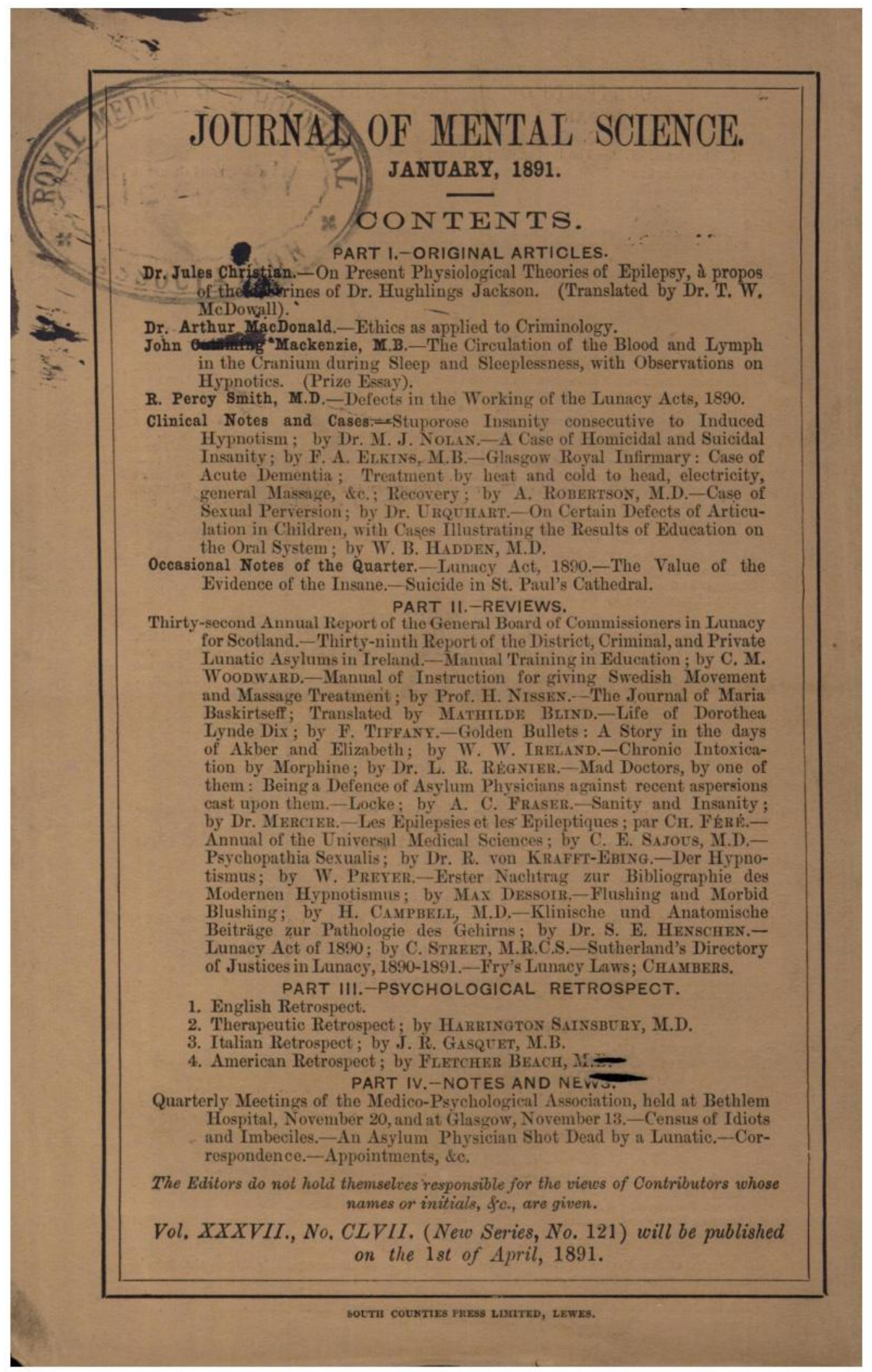

